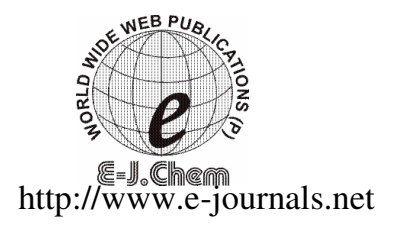

ISSN: 0973-4945; CODEN ECJHAO

E-Journal of Chemistry

2010, 7(4), 1359-1361

\title{
Synthesis of Some Bromo-Substituted 3-Aroyl Flavanones and Flavones
}

\author{
P. R. MAHALLE and N. T. KHATY* \\ Priyardarshini College of Engineering, Nagpur, India. \\ prmahalle@ rediffmail.com
}

Received 20 October 2009; Accepted 15 December 2009

\begin{abstract}
A series of bromo-substituted 3-aroyl flavanones and flavones have been synthesized. The identities of the new compounds synthesized have been developed on the basis of usual chemical transformation and IR, NMR spectral studies.
\end{abstract}

Keywords: Bromo-substituted compounds, 3-Aroyl flavanones, Flavones, Synthesis.

\section{Introduction}

Chalcones, flavanones and flavones were reported to have antibacterial, antifungal, anticancer, anti -HIV and anti-oxidant properties ${ }^{1-4}$. Flavanones and flavones play a pivotal role in the field of heterocyclic chemistry. These acts as a backbone for the compounds which possess diverse pharmacological and microbial activity ${ }^{5,6}$.

The present communication deals with the synthesis of bromo-substituted 3-aroyl flavones by employing two procedures $i$. $e$. one by the oxidation of 3 -aroyl flavanones in presence $\mathrm{SeO}_{2}$ as oxidizing agent which involves refluxing period of about $18 \mathrm{~h}$ and other method by using iodine crystal as the oxidizing agent which requires only $30 \mathrm{~min}$. The reaction was carried out in different solvents like DMSO, THF and dioxane.

\section{Experimental}

All the melting points reported are uncorrected. All the compounds synthesized were characterized on the basis of usual chemical transformation and IR, NMR spectral studies ${ }^{7}$. The IR spectra were recorded on a Perkin - Elmer FT-IR infrared spectrophotometer. The ${ }^{1}$ HNMR spectra were recorded on a Bruker-DRX $300 \mathrm{MHz}$ NMR spectrophotometer using TMS as an internal reference in DMSO-d6 as a solvent.

\section{1-(2-Hydroxy -3-bromo-5-methyl-phenyl)-3-phenyl-1, 3-propadione (1)}

It was prepared by the classical Baker -Venkatraman transformation ${ }^{8,9}$ from 2-benzoyloxy 3-bromo-5-methyl acetophenone using pulverized $\mathrm{KOH}$ in pyridine. 
3-Benzoyl-6-methyl-8-bromo flavanone(3) and 4'Methoxy-3-benzoyl-6-methyl-8bromo flavanone (5)

3-Benzoyl-6-methyl-8-bromo flavanone (3) and 4'methoxy-3-benzoyl-6-methyl-8-bromo flavanone (5) were prepared from the condensation of 1-(2-hydroxy-3-bromo-5-methyl-phenyl)-3-phenyl 1,3-propadione $(\mathbf{1}, 0.005 \mathrm{M})$ with benzaldehyde $(2,0.005 \mathrm{M})$ and anisaldehyde $(4,0.005 \mathrm{M})$ respectively in ethanol in presence of few drops of piperidine $(0.5 \mathrm{~mL})$. The reactions were carried out for $2 \mathrm{~h}$. The products were recrystallised form ethanol- acetic acid mixture.

\section{3-Benzoyl-6-methyl-8-bromo flavone (6) and 4'methoxy-3-benzoyl-6-methyl-8- bromo flavone(7)}

The target products were prepared by the oxidation of 3-benzoyl-6-methyl-8-bromo flavanone (3) and 4'methoxy-3-benzoyl-6-methyl-8-bromo flavanone (5), respectively with $\mathrm{SeO}_{2}$ in different solvents like DMF, THF and DMSO. The reaction mixture was refluxed for $18 \mathrm{~h}$ and the formation of the products was ensured with the help of TLC. The same products were prepared using Iodine as an oxidizing agent which just takes $30 \mathrm{~min}$ for the completion of the reaction. The Spectral data of the synthesized product are described as below:

IR $\left(\mathrm{cm}^{-1}\right): 1670(\mathrm{C}=\mathrm{O}), 2340(\mathrm{Ar}-\mathrm{H}), 1070(\mathrm{C}-\mathrm{O}-\mathrm{C}), 1440(\mathrm{C}=\mathrm{C})$. NMR: $\delta$ 7.0-7.4 (m, $12 \mathrm{H} \mathrm{Ar}-\mathrm{H}) ; \delta 5.5-6.0(\mathrm{~m}, 2 \mathrm{H}, \mathrm{CH}), \delta 2.2-2.3\left(\mathrm{~m}, 3 \mathrm{H}, \mathrm{CH}_{3}\right)$.

IR $\left(\mathrm{cm}^{-1}\right): 1690(\mathrm{C}=\mathrm{O}), 2360(\mathrm{Ar}-\mathrm{H}), 1050(\mathrm{C}-\mathrm{O}-\mathrm{C}), 1450(\mathrm{C}=\mathrm{C}) . \mathbf{N M R}: \delta$ 7.32-7.97 (m, 11H Ar-H); $\delta$ 5.5-5.9 (m, 2H, CH), $\delta 3.4-3.6\left(\mathrm{~m}, 3 \mathrm{H}, \mathrm{OCH}_{3}\right) ; \delta 2.2-2.4\left(\mathrm{~m}, 3 \mathrm{H}_{2} \mathrm{CH}_{3}\right)$.

IR $\left(\mathrm{cm}^{-1}\right): 1650(\mathrm{C}=\mathrm{O}), 2370(\mathrm{Ar}-\mathrm{H}), 1060(\mathrm{C}-\mathrm{O}-\mathrm{C}), 1450(\mathrm{C}=\mathrm{C}) . \mathbf{N M R}: \delta$ 7.2-7.8 (m, $12 \mathrm{H} \mathrm{Ar}-\mathrm{H}) ; \delta 2.2-2.3\left(\mathrm{~m}, 3 \mathrm{H}, \mathrm{CH}_{3}\right)$.

IR $\left(\mathrm{cm}^{-1}\right): \quad 1650(\mathrm{C}=\mathrm{O}), \quad 2370(\mathrm{Ar}-\mathrm{H}), \quad 1060(\mathrm{C}-\mathrm{O}-\mathrm{C}), \quad 1450(\mathrm{C}=\mathrm{C}) . \quad$ NMR: $\quad \delta .4-8.0$ $(\mathrm{m}, 11 \mathrm{H}, \mathrm{Ar}-\mathrm{H}) ; \delta 3.6-3.8\left(\mathrm{~m}, 3 \mathrm{H}, \mathrm{OCH}_{3}\right), \delta 2.34-2.46\left(\mathrm{~m}, 3 \mathrm{H}, \mathrm{CH}_{3}\right)$

\section{Results and Discussion}

The bromo-substituted 3-aroyl flavanones were prepared from the condensation of diketone with an aromatic aldehyde. The diketone was prepared by employing the classical BekarVenkatraman synthesis. Thus 3-benzoyl-6-methyl-8-bromo flavanone (3) and 4'-methoxy-3benzoyl-6-methyl-8-bromo flavanone (5) were synthesized by the condensation of 1-(2hydroxy-3-bromo-5-methyl phenyl)-3-phenyl-1,3-propadione (1) with benzaldehyde (2) and anisaldehyde (4) respectively in ethanol for two hours in presence of few drops of piperidine (Scheme 1). The products were recrystallised from ethanol-acetic acid mixture.<smiles>Cc1cc(Br)c(O)c(C(=O)CC(=O)c2ccccc2)c1</smiles><smiles>CCO[Pb]([O-])(O)Cc1ccccc1C=O</smiles><smiles>Cc1cc(Br)c(O)c(C(=O)CC(=O)c2ccccc2)c1</smiles><smiles>CCO[C@H](O)Cc1ccc(OC)cc1</smiles>

\section{Scheme 1}


In order to obtain the bromo-substituted 3-aroyl flavones, the flavanones $\mathbf{3}$ and $\mathbf{5}$ were oxidized using $\mathrm{SeO}_{2}$ for the reaction time of $16 \mathrm{~h}$ in various solvents like THF, DMSO and dioxane. Similarly, the same products were oxidized in presence of a single crystal of iodine $\left(\mathrm{I}_{2}\right)$ and it was observed that the reaction was completed just in $30 \mathrm{~min}$.<smiles>Cc1cc(Br)c2c(c1)C(=O)C(C(=O)c1ccccc1)C(c1ccccc1)O2</smiles>

3<smiles>COc1ccc(C2Oc3c(Br)cc(C)cc3C(=O)C2C(=O)c2ccccc2)cc1</smiles>

5<smiles>Cc1cc(Br)c2oc(-c3ccccc3)c(C(=O)c3ccccc3)c(=O)c2c1</smiles><smiles>COc1ccc(-c2oc3c(Br)cc(C)cc3c(=O)c2C(=O)c2ccccc2)cc1</smiles>

7

Scheme 2

Table 1. Characteristic data of the synthesized compounds

\begin{tabular}{ccccccc}
\hline Product & $\begin{array}{c}\text { Molecular } \\
\text { Formula }\end{array}$ & $\begin{array}{c}\text { Yield, } \\
\%\end{array}$ & M.p., ${ }^{\circ} \mathrm{C}$ & $\begin{array}{c}\text { Rf }(n \text {-hexane: } \\
\text { EtOAc) }\end{array}$ & $\begin{array}{c}\text { C, Found } \\
\text { (Calcd.) }\end{array}$ & $\begin{array}{c}\text { H, Found } \\
\text { (Calcd.) }\end{array}$ \\
\hline $\mathbf{3}$ & $\mathrm{C}_{23} \mathrm{H}_{17} \mathrm{BrO}_{3}$ & 75 & $137-138$ & $0.76(3: 2)$ & $65.61(65.57)$ & $4.05(4.07)$ \\
$\mathbf{5}$ & $\mathrm{C}_{24} \mathrm{H}_{19} \mathrm{BrO}_{4}$ & 75 & $149-151$ & $0.79(3: 2)$ & $63.90(63.87)$ & $4.22(4.24)$ \\
$\mathbf{6}$ & $\mathrm{C}_{23} \mathrm{H}_{15} \mathrm{BrO}_{3}$ & 65 & $189-191$ & $0.86(3: 2)$ & $65.85(65.89)$ & $3.59(3.61)$ \\
$\mathbf{7}$ & $\mathrm{C}_{24} \mathrm{H}_{17} \mathrm{BrO}_{4}$ & 70 & $196-199$ & $0.64(3: 2)$ & $64.10(64.16)$ & $3.83(3.81)$ \\
\hline
\end{tabular}

\section{Acknowledgment}

Authors are thankful to RSIC, CDRI Lucknow for providing the spectra and also to Dr. M. P. Singh, Principal Priyadarshini Engineering College, Nagpur for providing necessary facilities.

\section{References}

1. Billers D, Blodeau D and. Sliwa H, J Heterocyclic Chem., 1993, 30, 671.

2. Birt D F, Hendrich S and Wang W, Pharmacol Ther., 2001, 90, 157.

3. Yu D, Chen C H, Brossi A and Lee K H, J Med Chem., 2004, 47, 4072-4082.

4. Ungwitayatrom J, Samee W and Pimthon J, J Mol Struct., 2004, 689, 99.

5. Geirger W B and Conn J E, J Amer Chem Soc., 1945, 67, 112.

6. Laliberate R, Manson J, Warik H and Medewar G, Can J Chem., 1968, 46, 1952-1956.

7. Hatzade K M, Taile V S, Gaidhane P K, Haldar A G M and Ingle V N, Indian J Chem., 2008, 47B, 1260.

8. Baker W, J Chem Soc., 1933, 1381-1389.

9. Mahal H S, Rai H S and Venkatraman K, J Chem Soc., 1936, 866. 


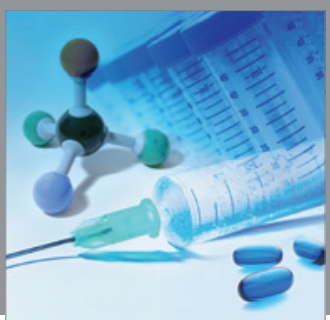

International Journal of

Medicinal Chemistry

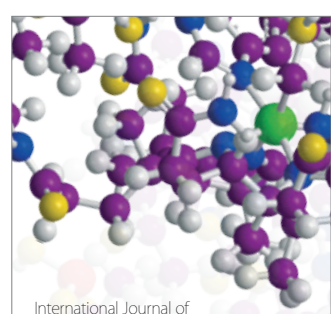

Carbohydrate Chemistry

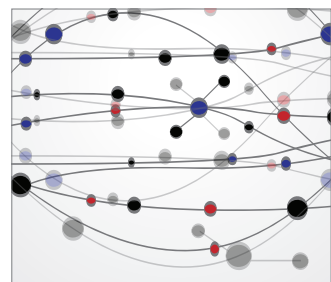

The Scientific World Journal
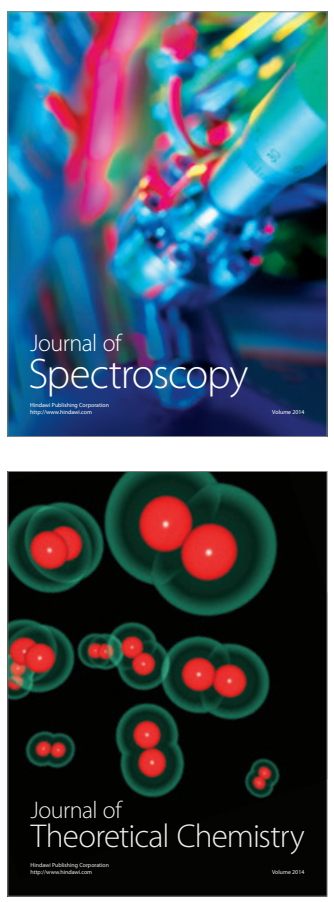
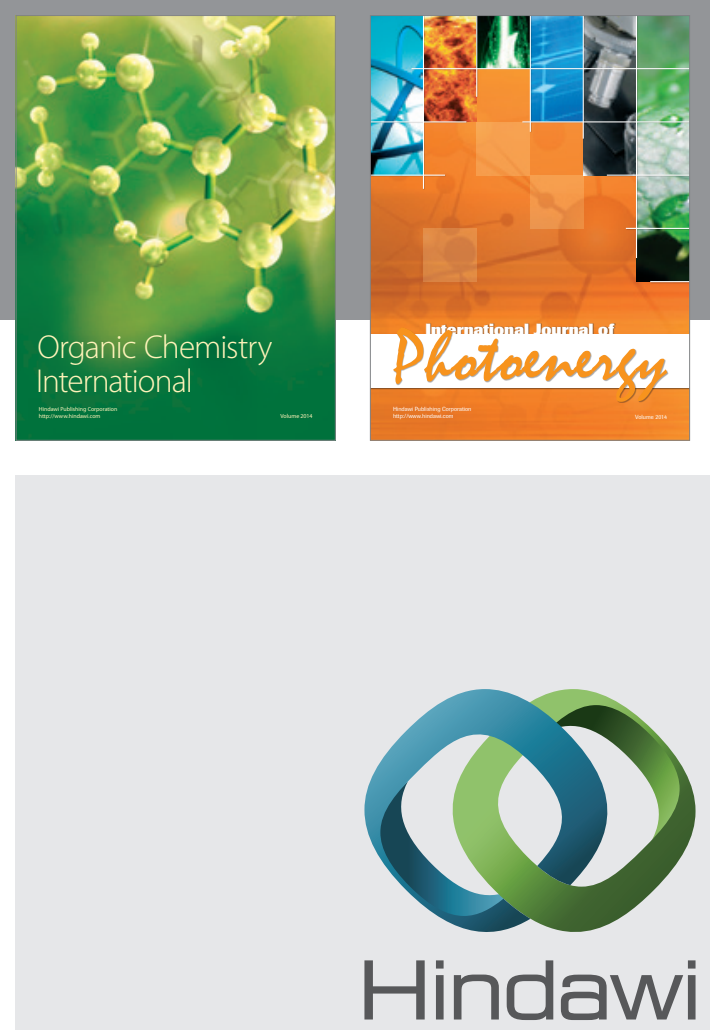

Submit your manuscripts at

http://www.hindawi.com
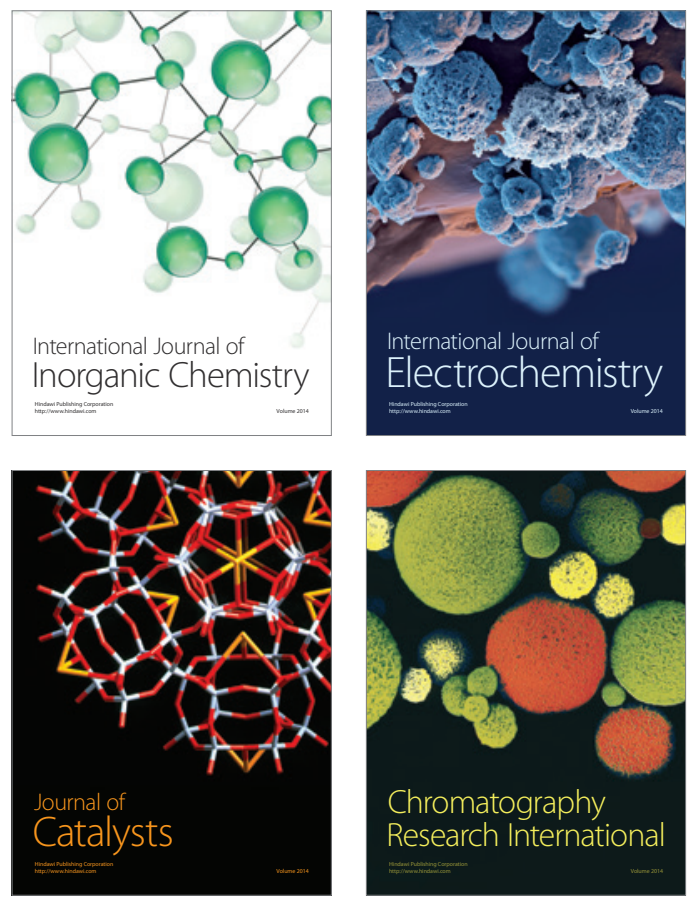
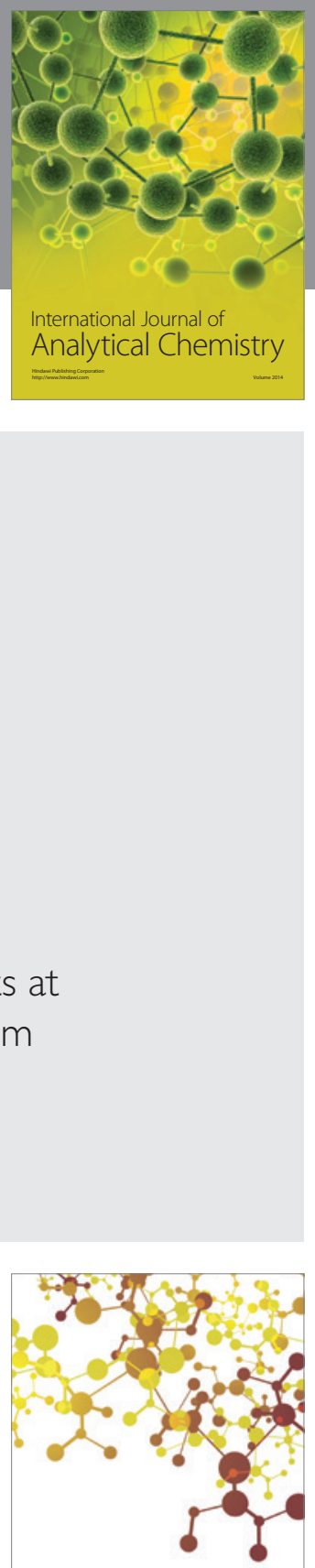

Journal of

Applied Chemistry
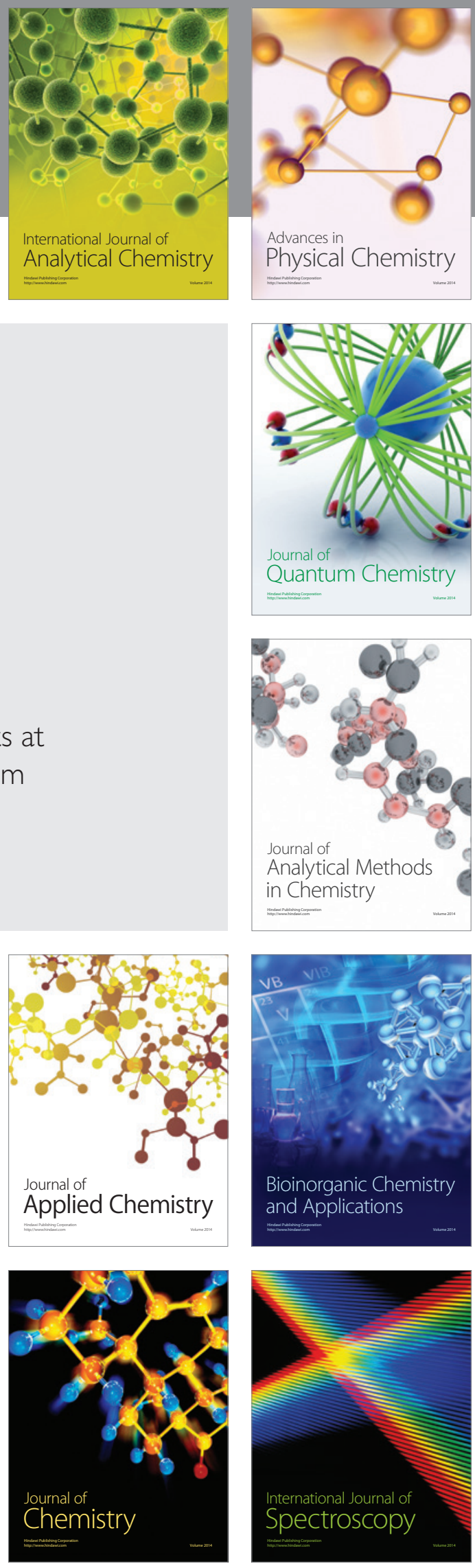